Academy of Ukraine.Vitaliy Gubarenko: Pages of creativity. Articles, research, memoirs. Kyiv: NMAU [in Russian].

4. Gubarenko, I. (2011). Roman romance. Kharkiv: Akta [in Russian].

5. Gubarenko, M. (2006). Gubarenko Irina. Ukrainian Musical Encyclopedia. Vol. 1. Kiïv: M. Rylsky Institute of Musical Folklore and Ethnography of the Ukrainian National Academy of Sciences [in Ukrainian].

6. Yermakov, Y. (1984). Components of success. Vechernyaya Odessa. August, 30 [in Russian].

7. Ignatieva, M. (1984). Duet of ballet and opera. Soviet Culture. September, 26 [in Russian].

8. Theaters of Odessa in the new season. Vechernyaya Odessa. 1984. October, 19 [in Russian].

УДК 784.4(477.86)

DOI https://doi.org/10.31723/2524-0447-2020-30-2-5

Ольга Романівна Фабрика-Процька

ORCID: 0000-0001-5188-1491

кандидат мистецтвознавства,

доцент кафедри музичної україністики

та народно-інструментального мистецтва

Навчально-наукового інституту мистеитв ДВНЗ «Прикарпатський національний університет

імені Василя Стефаника»

olgafp4@ukr.net

\title{
ЗАГАЛЬНА ХАРАКТЕРИСТИКА НАРОДНОГО МУЗИЧНОГО ІНСТРУМЕНТАРІЮ СЛОВАЧЧИНИ В ІСТОРИЧНОМУ АСПЕКТІ
}

Мета роботи - дослідження народного музичного інструментарію Словаччини в історико-культурному й органологічному контекстах. Головним принципом є комплексний підхід до вирішення поставлених завдань. Методологія дослідження полягає у використанні теоретичного, історичного, культурологічного, мистецтвознавчого підходів, що дало змогу розкрити взаємодію тенденцій, репрезентованих явищами полікультурності, а також взаємозв'язок між етносами, регіона-

(C) Фабрика-Процька О. Р., 2020 
ми та країнами в наш час. Стаття грунтується на методологічних принципах історичного підходу до аналізу мистецьких явищ. Спільний етнографічний кордон між українським та словацьким населенням у районі Закарпаття і Пряшівщини сприяв культурним, економічним та фольклорним зв'язкам між ними. Народна інструментальна, вокальна та танцювальна культура русинів-українців Східної Словаччини самовдосконалювалася та пристосовувалася до нових форм побутування, у сучасному суспільному житті є складовою частиною мистецького процесу. Наукова новизна дослідження полягає у спробі комплексного висвітлення народного музичного інструментарію, який побутує у Словаччині, в історичному аспекті. Висновки. У наш час на території Східної Словаччини посилюються процеси словакізації українського населення, взаємовпливів як у вокальному, так і в інструментальному виконавстві (у музичній мові, стилях, різноманітній техніці гри тощо). У різних сферах побуту русинів-українців та словаків використовуються сопілки, флейти, фуяри, кларнети, волинки, скрипки, контрабаси, гармоніки, баяни, акордеони тощо. Музично-інструментальна культура Східної Словаччини несе в собі важливу етнічно-інтеграційну функцію, що сприяє збережкенню етнічної, національної та культурної ідентичності, а також популяризації музичного фольклору. Усвідомлення сутності музичного інструментарію неможливе без урахування всього історико-культурного контексту - специфіки соціальної та етнічної свідомості, побуту, обрядів, типу господарської діяльності.

Ключові слова: історія, народний музичний інструментарій, Словаччина, виконавство, музичний фольклор, органологія.

Fabryka-Protska Olga Romanivna, Candidate of the Art Critic, Associate Professor at the Department of Musical Ukrainian Studies and Folk Instrumental Music Art of the Institute of Art of Vasyl Stefanyk Precarpathian National University

General characteristics of popular musical instruments of Slovakia in the historical aspect

Research objective. The aim of the study is to uncover the history of folk musical instruments in the historical and cultural context. The main principle is a comprehensive approach to solving the tasks. The methodology of the study is to use theoretical, historical, cultural, artistic and scientific approaches, which allowed us to reveal the interaction of trends represented by the phenomena of multiculturalism, as well as the relationship between ethnicities, regions and countries in our time. The article is based on the methodological principles of the historical approach to the analysis of artistic phenomena. The common ethnographic border between the Ukrainian and Slovak populations in the Transcarpathian and Presov regions contributed to cultural, economic and folklore ties between them. Self-improving and adapting to new forms of life, the folk instrumental, vocal and dance culture of the Ruthenian-Ukrainians of Eastern Slovakia is largely a part of the modern social life in modern public life. The scientific novelty of the study lies in the attempt to comprehensively cover folk musical instruments that are 
historically present in Slovakia. In more than 230 settlements of northeastern Slovakia, along the Slovak-Polish state border, Ruthenian-Ukrainians, which are the westernmost ethnic branch of the Ukrainian people, live today. The practical significance of the study. Research materials can be used in the fields of arts, cultural studies, as well as to serve as a basis for further research in specialized and higher education institutions. Conclusions. Nowadays, the processes of Slovakization of the Ukrainian population, mutual influences both in vocal and instrumental performance (in musical language, styles, various playing technique, etc.) are increasing in the territory of Eastern Slovakia. Pipes, flutes, fujars, clarinets, bagpipes, violins, double basses, harmonicas, accordions, accordions, etc. are used in various spheres of life of RuthenianUkrainians and Slovaks. The musical-instrumental culture of Eastern Slovakia has an important ethno-integration function that promotes the preservation of ethnic, national and cultural identity, as well as the popularization of musical folklore. Along with Slovak songs and instrumental tunes, Polish, Romanian, Gypsy, Ruthenian, Ukrainian, Czech, and Hungarian works are performed today. The current state of folk instrumental performance of Slovakia is characterized by the partial preservation of the local tradition, the functioning of such musical instruments as guitars, mandolins, various harmonics, in particular heligocar. Today, more than 10 Ukrainian cultural societies are active in Eastern Slovakia. The main task of the societies is to promote and revive history, the Ukrainian language and culture. To this end, various art competitions, festivals, master classes are organized and held. Awareness of the essence of musical instruments is impossible without taking into account the entire historical and cultural context - the specifics of social and ethnic consciousness, life, rituals, type of economic activity.

Key words: history, folk music instruments, Slovakia, performance, musical folklore, organology.

Фабрика-Процкая Ольга Романовна, кандидат искусствоведения, доцент кафедры музыкальной украинистики и народно-инструментального искусства Учебно-научного института искусств ГВУЗ «Прикарпатский национальный университет имени Василия Стефаника»

Общая характеристика народного музыкального инструментария Словакии в историческом аспекте

Целью работы является исследование народного музыкального инструментария Словакии в историко-культурном контексте. Главным принципом является комплексный подход к решению поставленных задач. Методология исследования заключается в использовании теоретического, исторического, культурологического, искусствоведческого подходов, что позволило раскрыть взаимодействие тенденций, представленных явлениями поликультурности, а также взаимосвязь между этносами, регионами и странами в наше время. Статья основывается на методологических принципах исторического подхода к анализу художественных явлений. Общая этнографическая гранииа между украинским и словацким населением в районе Закарпатья и Пряшевщины способствовала культурным, экономическим и фольклорным связям между 
ними. Самосовершенствуясь и приспосабливаясь к новым формам бытования, народная инструментальная, вокальная и танцевальная культура русинов-украинцев Восточной Словакии в значительной степени в современной общественной жизни является составной частью художественного процесса. Научная новизна исследования заключается в попытке комплексного освещения народного музыкального инструментария, который бытует в Словакии, в историческом аспекте. Выводы. В настоящее время на территории Восточной Словакии усиливаются процессы словакизации украинского населения, взаимное влияние как в вокальном, так и в инструментальном исполнительстве (в музыкальном языке, стилях, разнообразной технике игры и так далее). В различных сферах быта русинов-украинцев и словаков используются свирели, флейты, фуяры, кларнеты, волынки, скрипки, контрабасы, гармоники, баяны, аккордеоны и другие инструменты. Музыкально-инструментальная культура Восточной Словакии несет в себе важную этнически интеграционную функцию, способствует сохранению этнической, национальной и культурной идентичности, а также популяризации музыкального фольклора. Осознание сущности музыкального инструментария невозможно без учета всего историко-культурного контекста - специфики социального и этнического сознания, быта, обрядов, типа хозяйственной деятельности.

Ключевые слова: история, народный музыкальный инструментарий, Словакия, исполнительство, музыкальный фольклор, органология.

Актуальність теми дослідження. Карпатський регіон є неповторним природно-культурним ареалом для українців, поляків, словаків, чехів, угорців, румунів. Словацька республіка 3 багатонаціональним складом населення через географічне розташування та складні історичні умови стала батьківщиною не лише словаків, але й представників інших народів, які прийнято називати етнічними групами чи національними меншинами. Народний музичний інструментарій є явищем матеріальної та духовної культури. Його конструкція, стрій, матеріал, музично-виразові та техніко-виконавські можливості в комплексі відображають специфіку музичного мислення, історичні традиції, рівень практичних, наукових знань, світогляд [1].

За висловом мультиінструменталіста зі Словаччини Міхала Сметанки, один із найбільших скарбів культури та традицій, які нам залишили наші предки, - музичні інструменти, які $є$ засобом вияву гармонії між людською душею та зовнішнім світом. Музичні інструменти предків передусім не були призначені для розваги. Вони були важливим доповненням ландшафту, життя громад, спілкування та передачі інформації, а також частиною широкого контексту існування [8]. 
Мета дослідження полягає у висвітленні народного музичного інструментарію, який побутує у Словаччині, в історичному аспекті.

Наукова новизна. Народний музичний інструментарій протягом тривалого часу досліджували науковці як України (М. Лисенко, Ф. Колесса, Г. Хоткевич, К. Квітка, С. Грица, Л. Черкаський, І. Мацієвський, С. Хащеватська, Л. Кіндратюк, М. Хай, Б. Яремко, В. Шостак, В. Дутчак, П. Круль, Б. Кіндратюк, Ю. Волошук, Л. Пасічняк, Ю. Гулянич та інші), так і закордонних країн (К. Закс, Е. Горнбостель, Б. Барток, О. Ельшек, Л. Ленг, С. Мерчинський, Й. Грушовський, М. Сметанка та інші).

Тривала приналежність як словацьких земель, так і Закарпаття й Галичини до імперії Габсбургів, слов'янське спільне коріння, сусідне розташування українських та словацьких етнічних територій, подібність типу господарства та побуту, які сприяли інтенсивним контактам між українцями та словаками, стимулювали появу наукових досліджень. Необхідність вивчення народного музичного інструментарію русинів Східної Словаччини зумовлена декількома чинниками: українське населення Пряшівщини протягом багатьох сторіч проживало в надзвичайно важких умовах національного та соціального гноблення, що сприяло значному гальмуванню його культурного та національного розвитку; географічні й економічні умови русинів-українців, тривала ізоляція внаслідок розташування регіону спричинили збереження архаїзмів у народній культурі, що створює сприятливі умови для вивчення русинів-українців із боку етнології, народознавства, культурології тощо. Незважаючи на майже тисячолітнє відторгнення цього населення від корінного українського народу, воно зуміло зберегти давньоруський та загальноукраїнський характер своєї традиційної культури, хоч, правда, з деякими новими оригінальними елементами; незважаючи на те, що культура русинів-українців пов'язана з материнською культурою українського народу, все таки дотепер вона переплітається з культурними впливами словаків, через спільність території. Територію Словаччини протягом віків населяли поляки, словаки, українці, угорці, роми, німці, що сприяло міжетнічним відносинам та впливало на взаємозв'язки тощо.

Словаки й українці Пряшівщини, Закарпаття та Галицької Лемківщини практично не відчували різниці ні в розмові, ні 
в піснях. Пряшівщину вважають природним центром культурного, освітнього та релігійного життя українців-русинів на території сучасної Словаччини.

Виклад основного матеріалу. Українське (русинське) населення, яке живе на території північно-східної Словаччини, було протягом багатьох століть ізольоване від свого материнського роду, що призвело до його часткової денаціоналізації та втрати деяких характерних етнографічних рис. Та наперекір цьому тут збереглася специфіка української / русинської народної культури, яка має свої виразні етнічні риси, адже формувалась у важких господарських і соціальних умовах.

За висловом Івана Чижмара, на розвиток музичної культури русинів, лемків на території Словаччини протягом історичних етапів впливала церква. Духовенство було переконане, що християни повинні оспівувати Бога людським голосом, а не «бездухими музичними інструментами» [2]. Вони трактували всі музичні інструменти за поганські, диявольські, від яких іде лише зло, гріх, бо біля них танцюють і веселяться. Прикладом слугують іконописні пам'ятки, на яких зображені музичні інструменти в руках чорта, сатани в пеклі, які грають до танцю. Мешканці сіл прислухались до настанов духовенства, але не припиняли створювати мелодії в побуті та під час важкої праці.

Найбільш архаїчна верства інструментальної музики Карпатського регіону пов'язана з награванням на мундштучних інструментах на кшталт конусоподібної труби без грифних отворів: «трумбета, тембіта», "fujara trombita, bacovska truba". Інструмент складається з конічної труби з розтрубом та мундштука. На території Словаччини побутують такі типи трембіт, як: тромбіта 3 кори та фуяра тромбіта, яка являє собою дерев'яну трубу без грифних отворів, з конічним розтрубом i мундштуком, має дві смерекові або ялицеві половинки, що утворюють суцільну трубу довжиною до 5,50 метрів. Трембіти склеюються живицею, а зовні огортаються черешневою або березовою корою та скріплюються обручами з дерева або жерсті. У верхній вхідний отвір вставляться мундштук для створення звуку, а розширена нижня частина інструмента має назву "roztrub". Характерною особливістю виготовлення фуяри тромбіти є те, що під час заготівлі деревина розпилювалася і використовувалася повністю. Через значні розміри 
словацьких трембіт вони скріплювалися обручами та корою, а закарпатські аналоги - корою або обручами [1].

Ще одним сигнальним музичним інструментом, що функціонує серед пастухів для комунікації (спілкування з населенням долини на пасовиську), є фуяра тромбіта (bacovska truba). Його особливістю є спосіб тримання в руках, двоє людей один трембітає, а інший несе розтруб на плечі, а якщо був один трембітар, то він змушений був розтруб класти на розлоге дерево у зв'язку з довжиною інструмента (до 5,50 м). Функційно такий інструмент споріднений із великою трембітою, що побутує на Закарпатті, але в обрядовій сфері не використовується. 3 акустичного погляду інструмент має широкий спектр від 3 до 16 обертонів натурального звукоряду, а робочий діапазон сягає від 3 до 11 обертонів. Ареал розповсюдження - практично всі гірські місцевості Словаччини від Малих Карпат до Високих Татр [1].

У північній частині Словаччини побутували кручені труби 3 вільхової кори, довжиною від 1,0-1,5 м. Діапазон обмежений - від 3 до 6 обертону, тембр м'який. Інструмент також функціонував як сигнальне знаряддя пастушої традиції. Серед відмінностей, що відрізняють словацьку традицію від української (закарпатська) інструментальної традиції, перевага законсервованості архаїчних форм і типів народного інструменталізму.

Імітація трембітного сигналу є більш варіативною, інтонаційно чергується зі стрибками та поступовим розвитком. Функція трембіти нівелювалась і перейшла у використання до вівчарів із появою церковних дзвонів (XVII-XVIII ст.). Мелодична лінія словацьких трембітних композицій побудована на фанфарних інтонаціях, які іноді наповнюються поступовим рухом. Етноорганологи вважають, що найархаїчнішими $\epsilon$ словацькі композиції, відповідно закарпатські трембітні награвання $є$ більш молодшими від словацьких. На думку Н. Гуляєвої, характер закарпатських награвань, вільно-імпровізаційна манера виконання, певна варіантна розбіжність між окремими строфами форми, а також досить значний масштаб сигналів, імовірно, можуть вказувати на існування програмних сюїт-поет у репертуарі трембітарів [1, с. 230-235].

На території Словаччини в першій половині XX ст., окрім циганських капел, функціонували змішані музики (роми та слов'яни). Музиканти самотужки навчалися один від одного, 
грали «самі для себе», на різноманітних забавах, весіллях, вечірках. Грі на музичних інструментах навчалися лише хлопчики. Уважалось, що дівчатам належить веретено, віник i куховарення, а не гра на інструментах. У період війни села були знищені, спалені, зруйновані. Мало збереглося архівних матеріалів, які б висвітлювали функціонування музичного інструментарію в середовищі русинів. 1945 р. поклав початок розвитку народної культури в русинський селах. 31948 p. почали діяти фольклорні експедиції, однак мало хто цікавився народним музичним інструментарієм та грою на ньому. У 1951 р. було створено Культурний союз українських трудящих (далі - КСУТ), який сприяв створенню по селах вокальних та інструментальних фольклорних колективів.

Протягом десятиріч музикант, етнограф, фотограф Іван Чижмар збирав колекцію музичних інструментів, яка зберігається в Музеї української культури у Свиднику. Виставкову колекцію інструментарію поділено на тематичні округи: архівні джерела, дитячі музичні іграшки, пастуші труби та роги, сопілки - «пищки», дуди, ударні інструменти, мандоліни, бандури, цимбали, смичкові інструменти, гармошки та сучасні музичні інструменти [2]. Зокрема, серед експонатів сопілка - типовий український народний музичний інструмент, виготовлений найчастіше із кленового або горіхового дерева. Звук сопілки подібний до звуку флейти. Уживається самостійно як музичний інструмент, а також в оркестрах народних інструментів. Часто виготовляли їі як двоїсту свистівку - дводенцівку; бубни - музичні інструменти, які видають звук ударом палички аби іншого предмета. У русинському регіоні Східної Словаччини побутували малі бубни, якими скликали селян для повідомлення новин. Бубни складаються із дерев'яної або металічної рами, у вигляді круга. Рама з одного боку або із двох обтягнута шкірою. Бубни підсилювали ритм в духових, симфонічних і джазових оркестрах. До струнних щипкових інструментів у музейній експозиції належать балалайка, домра, бандура. Цимбали - струнний ударний інструмент, який сприяє розвитку гармонійної уяви і багатства мелодій. У XVIII-XIX ст. інтенсивно розвивалось виробництво цимбалів. Побутувало ансамблеве, а із плином часу сольне музикування.

Найпоширенішими музичними інструментами на території Словаччини дослідники вважають смичкові інструменти. 
Ще й дотепер у народному середовищі можна віднайти давні музичні інструменти, імітації професійних інструментів. Скрипка (гуслі) або контрабас найчастіше виготовлялись так: нижня дошка - $з$ явора, верхня - $з$ ялиці, смичок - з букового дерева. Скрипка видовбувалася з вербового дерева, верхня дошка була з ялиці. Такий спосіб виготовлення скрипки / гуслів був значно поширеним в українському (русинському) регіоні Східної Словаччини ще до Другої світової війни. Гармошки та «гелігонки» були улюбленими інструментами в побуті, використовуються й у сольному музикуванні, передусім на території Східної Словаччини. Русини і лемки музикували на дуді, дудках, скрипках та контрабасах.

Поступово інструментальні капели поповнили сопілка, кларнет, бубон, саксофон, гармоніки, які поступово замінили контрабаси. Часто гра на цих двох інструментах призводила до дисгармонічних звуків. Найбільш поширеним інструментом у танцювальній музиці була скрипка (гуслі). Капелу, до складу якої входили скрипка, сопілка та бубон, називали «гудаци» - як перша назва групи, яка грала по весіллях, кермешах та інших забавах. Також функціонували такі склади капел: скрипка, пищалка, контрабас, мандоліна, різновиди гармоніки. Через брак коштів музиканти вручну виготовляли музичні інструменти, були спеціальні майстри. Серед відомих майстрів із виготовлення скрипки варто назвати Симка Вархола, Яна Лаката, Деметра Швеця, Михала Дунчака й інших. Населення цікавилося інструментами, які продавалась на ярмарках, найчастіше це різновиди гармоніки, згодом на ринку з'явилися мандоліни, гітари і балалайки.

У другій половині ХХ ст. у регіонах Маковиці, Лабірській та Снинській долині, в околицях Старої Любовні, у Спиші протягом десятиріч функціонували циганські (ромські) капели, які зростали й виховувались у власних культурних умовах, пристосувалися до фольклору сільського середовища, у якому жили. Серед найбільш відомих ромів-музикантів у с. Крайня Поляна тривалий час був Михал Грундза, якого мешканці села називали «пан зо златыма пальцями, котрый не одному русинови грав на весіллю <...> [4]. Також популярними були талановиті музиканти із сіл Дубова, Куримка, Бехерова і Варадки. У 60-х pp. XX ст. у Крайній Бистрі біля Свидника відомим був музикант Ян Ванько на прізвисько «Бунгер», який також грав по весіллях разом із капелою. У Шарішським 
Чорнім функціонувала циганська капела родини Ференцових. У селах Хмельова, Ладомирова, Межілаборець, Гуменного, Снини, Старой Любовні також побутували циганські та цигансько-слов'янські інструментальні музики. За кількістю музикантів і музичними інструментами склад гуртів був дуже різноманітним. Найпростіший склад $-3-5$ та більше музик. Серед музикантів завжди домінував керівник («предник»), який перший починав мелодію.

Натепер інструментальні капели доповнилися кларнетами, саксофонами, електрогітарами. Кожна група інструментів підсилена тричі. Багато народних капел долучає гармоніку замість контрабасів. У процесах трансформації форм побутування народно-пісенної культури й обрядовості, а також взаємодії пісенної традиції і новотворчості, зокрема пов'язаної із впливом словакізації сучасної культури русинів-українців, виявлено, що: а) місцеве русинське піснетворення вплітаються цілі образно-поетичні кліше, узяті зі словацького фольклору; б) усе, що є особливим у змісті і формі як лемківського, так і русинського фольклору, не відділяє їх від загального масиву традиційної музично-пісенної й усної словесності українського народу, не виокремлює їх, а навпаки, доповнює, збагачує цей масив неповторними елементами і рисами [3].

У крихітному селі Брутовце діє Інтерактивний музей музичних народних інструментів, заснований музикантом, мультиінструменталістом, викладачем музики, виробником народних музичних інструментів, промоутером та популяризатором словацької народної культури, колекціонером та цінителем народної музики Міхалом Сметанкою. Провести час у цьому місці та слухати його інтерпретацію інструментальних демонстрацій - це нетрадиційний досвід. Митець зібрав у своїй колекції понад 500 музичних інструментів з усього світу, мав на меті поділитися багатством колекції, іiі історіями. «Створення музичного музею припадає на період 1995-2005 рр., функціонування майстерні ремесел у Спішському Хрхові, де Міхал Сметанка та Павол Урда проводили низку громадських, освітніх та культурних заходів для широко загалу, а також заклали основу для колекції музичних інструментів. Через недостатню просторову ємність, захищеність музею музичних інструментів, а також незадовільні умови для зберігання музичних інструментів музейну колекцію почали готувати до встановлення та постійної виставки в селі Спішський Хрхов 
у формі MUSEUM у 2017-2018 pp.» [7]. Початково колекція музичного інструментарію була зосереджена на зборі народних музичних інструментів Карпатського регіону, з акцентом на аерофони. Однак поступово колекція почала поповнюватись хордофонами, ідіофонами поза Карпатами. Створена експозиція поступово була перенесена до традиційного дерев'яного будиночка у Брутовце у 2008-2010 pp. У 2010 р. Словацький національний музей додав реєстр Музею народних музичних інструментів у Брутовце до реєстру закладів, що мають характер музейної презентації, за реєстраційним номером ZMP/42/2010 [7]. Музей функціонує як місце музичної освіти для дітей, як місце дослідження для етноорганологів, музикантів та громадськості. Музей музичних інструментів зберігає та популяризує регіональні народні музичні інструменти, вказує на їхні особливості й унікальність у контексті світового музичного інструментарію. Невід'ємною частиною інтерактивної презентації $є$ можливість побачити регіональні відмінності, матеріали, функціонування, почути звук тощо.

Широка мережа колективів народної художньої самодіяльності різних жанрів розвиваються при організаціях Союзу русинів-українців Чехії та Словаччини. Це інструментальні фольклорні групи, ансамблі, дитячі колективи, які популяризують свою культуру у селах та містах як на території Словаччини, так і за пї межами.

Висновки. Отже, варто констатувати, що сусіднє розташування українських та словацьких етнічних територій, подібність типу господарства та побуту, тривала приналежність словацьких земель до імперії Габсбургів, слов'янське спільне коріння сприяли інтенсивним контактам між українцями та словаками, стимулювали появу наукових досліджень.

Народний музичний інструментарій, що побутував та функціонує дотепер у Східній Словаччині, пов'язаний зі специфікою етнічної свідомості, побутом, обрядами і типом діяльності русинів-українців, інших етнічних і субетнічних груп. Характерними є: 1) часткове збереження місцевої традиціï, функціонування таких музичних інструментів, як гітари, мандоліни, гармоніки, гелігонки, бубни великі та малі, ліри, цимбали, скрипки, віолончель, контрабас, дзвоники, спіжак, клепач, рапкач, дримба, баян, акордеон, різноманітні дудки, ріжки, трембіти, дво- або триметрові дерев'яні труби з воронкоподібним резонатором на кінці, обвиті черешневою корою, 
сопілки, флейти, фуяри, кларнети, волинки; 2) розвиток процесів словакізації українського населення, взаємовпливів як у вокальному, так і в інструментальному виконавстві (у музичній мові, стилях, різноманітній техніці гри тощо); 3) репертуар мистецьких колективів збагачується, доповнюється, оновлюється; 4) поряд зі словацькими піснями та мелодіями звучать польські, румунські, циганські, русинські, українські, чеські, угорські. Серед жанрів варто назвати родинно-побутові (весільні, ладанки (латканя, ляпканя), мелодії до вінчання, до молодого, до нареченої) та необрядові (ліричні, жартівливі, до танцю тощо). Незважаючи на різноманітні процеси, які відбуваються в наш час, традиційна музично-інструментальна культура Словаччини зберігає етнічну, національну та культурну ідентичність, виконує важливу етнічно-інтеграційну функцію, що сприяє популяризації народного музичного інструментарію в Карпатському регіоні.

\section{СПИСОК ЛІТЕРАТУРИ}

1. Гуляєва Н. Деякі паралелі в інструментальній музиці України і Словаччини. Словацько-українські взаємини в області історії, культури, мови та літератури. Науковий збірник музею української культури у Свиднику / гол. ред. М. Сополига. 2007. № 24. 495 с.

2. Музей української культури у Свиднику. URL: http://www. snm.sk/?muzeum-ukrajinskej-kultury-uvodna-stranka.

3. Фабрика-Процька О. Функціонування словацько-українського пісенного фольклору на прикладі фестивалю «Маковицька струна»). Питання культурології. Вісник Київського національного університету культури і мистеитв. Серія «Музичне мистеитво». 2019. T. 2. № 1. C. 71-79.

4. Чижмар I. Музичні інструменти. Свидник : МУК, 1972. 72 с.

5. Чижмар I. Народны співанкы, музыка і танці русинів. Выходной Словакії. Свидник, 2009. 400 с.

6. Elschek O. Piesne a hudba. Slovensko. Lud. Cast II. Bratislava, 1975. S. 1083.

7. Histyria múzea. Muzik Muzeu. URL: https://muzikmuzeum.sk/o-nas/. o-nas/.

8. Smetanka M. O nas. Muzik Muzeu. URL: https://muzikmuzeum.sk/

\section{REFERENCES}

1. Gulyaeva N. (2007) Some parallels in the instrumental music of Ukraine and Slovakia. Slovak-Ukrainian relations in the field of history, culture, language and literature. Scientific collection of the Museum of Ukrainian Culture in Svidnyk. № 24. Editor-in-chief M. Sopoliga. Svidnyk. (in Slovakian) 
2. Museum of Ukrainian Culture in Svidnyk. URL: http://www.snm.sk/ ?muzeum-ukrajinskej-kultury-uvodna-stranka.

3. Fabryka-Protska O. (2019) Functioning of the Slovak-Ukrainian song folklore on the example of the Makovytska Struna festival). Issues of cultural studies. KNUIM Newsletter. Musical Art Series. Vol 2, № 1, Kyiv (in Ukrainian) (in Slovakian)

4. Chizhmar I. (1972) Musical Instruments, Svidnyk: MUK (in Slovakian)

5. Chizhmar I. (2009) Folk Songs, Music and Dance of the Ruthenians of the Original Slovakia. Svidnyk (in Slovakian)

6. Elschek O. (1975) Songs and Music. Slovakia. Lud. Cast II. Bratislava (in Slovakian)

7. Histyria múzea. Muzik Muzeu. URL: https://muzikmuzeum.sk/o-nas/.

8. Smetanka M. O nas. Muzik Muzeu. URL: https://muzikmuzeum.sk/ o-nas/.

УДК 78.01/.08+786.6

DOI https://doi.org/10.31723/2524-0447-2020-30-2-6

\author{
Анна Павловна Копейка \\ ORCID: 0000-0001-6291-9571
}

аспирантка кафедры истории музыки и музыкальной этнографии

Одесской национальной музыкальной академии имени

A. В. Неждановой

anna.kopejka@gmail.com

\title{
СТИЛЕВОЙ ФЕНОМЕН ЖАННЫ ДЕМЕСЬЁ: ИСТОРИЧЕСКИЕ И КОМПОЗИЦИОННЫЕ АСПЕКТЫ
}

Цель работы - создать стилевой портрет выдающейся франиузской органистки, пианистки, композитора середины ХХ века Жанны Демесьё в историческом контексте франиузской органной традиции. Методология исследования состоит в использовании аналитического, биографического, историко-логического, компаративного методов. $\mathrm{Ha}$ учная новизна работы заключается в анализе композиторского метода и выделении стилевых особенностей Жанны Демесьё, чье творчество существенно повлияло на формирование современной франиузской органной школы. В статье приводится краткий исторический очерк основных тенденций франиузской органной школы, сложившихся к началу

(c) Копейка А. П., 2020 